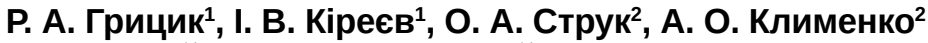
НАЦІОНАЛЬНИЙ ФАРМАЦЕВТИЧНИЙ УНІВЕРСИТЕТ IВАНО-ФРАНКІВСЬКИЙ НАЦІОНАЛЬНИЙ МЕДИЧНИЙ УНІВЕРСИТЕТ

\title{
ДОСЛІДЖЕННЯ ПРОТИЗАПАЛЬНОЇ АКТИВНОСТІ ЕКСТРАКТІВ ПОЛИНУ ГІРКОГО ТА ПОЛИНУ ЗВИЧАЙНОГО ЗА УМОВИ ПАТОЛОГІЇ РІЗНОГО ГЕНЕЗУ
}

Вступ. До рослин, що мають багатовіковий досвід використання в медицині, належать види роду Полин, які застосовують як апетитні, глистогінні, бактерицидні, жовчогінні та протизапальні засоби. Ïх дія зумовлена наявністю різних груп біологічно активних сполук.

Мета дослідження - вивчити протизапальну активність екстрактів полину гіркого і полину звичайного на моделях карагенінового та фрормалінового набряків.

Методи дослідження. Для визначення протизапальної активності екстрактів трави полину гіркого і полину звичайного за умови патології різного генезу використовували дві методики на моделях асептичного запалення (карагеніновий та формаліновий набряки), які рекомендував Державний експертний центр МОЗ України для доклінічних досліджень і встановлення антиексудативної активності. Дослідження та аналіз отриманих експериментальних даних проводили в порівнянні з препаратом із групи нестероїдних протизапальних засобів - натрію диклофенаком та кверцетином.

Результати й обговорення. Порівняльне вивчення протизапальної активності екстрактів полину гіркого і полину звичайного при карагеніновому набряку, який характеризувався циклооксигеназним шляхом запалення, показало, що вони проявляли антиексудативну дію протягом усього експерименту. Найбільше пригнічення набряку спостерігали на 5 год з моменту введення фрлогогенного агента, що свідчило про вплив екстрактів полину гіркого і полину звичайного на медіатори запалення - простагландини. При формаліновому набряку антиексудативна активність екстрактів проявлялась уже на 3 год і підвищувалась до кінця експерименту, що вказувало на пригнічення активності медіаторів запалення.

Висновок. Встановлено виражену протизапальну дію екстрактів полину гіркого і полину звичайного, які впливають на медіатори запалення - простагландини, їх можна використовувати як протизапальні засоби при запальних прочесах підшлункової залози та жовчного міхура.

КЛЮЧОВІ СЛОВА: протизапальна дія; полин гіркий; полин звичайний; карагеніновий набряк; формаліновий набряк.

ВСТУП. Фармакотерапія запального процесу залишається актуальною проблемою сучасної медицини. Однією з груп препаратів, які широко використовують при лікуванні запальних процесів в організмі, $є$ нестероїдні протизапальні засоби. Незважаючи на їх безсумнівну ефективність, їм притаманний ряд побічних ефректів, що обмежує застосування в клініці. Типова побічна дія нестероїдних протизапальних засобів пов'язана з механізмом дії цієї групи препаратів [1-6]. Використання орітопрепаратів дає можливість зменшити або повністю запобігти проявам традиційних побічних ефектів.

Трава полину гіркого (Artemisia absinthium L.) містить ефрірну олію (0,5-2,0 \%), фрлавоноїди, таніни, лігнани, органічні кислоти, каротин і віта() Р. А. Грицик, І. В. Кіреєв, О. А. Струк, А. О. Клименко, 2020. мін С. До складу ефрірної олії трави входять біциклічні монотерпеноїди: пінен, кадинен, кетон туйон і туїловий спирт, сесквітерпеноїди: фреландрен, $\beta$-каріофилен, у-сепінен, сесквітерпенові спирти - абсинтин, анабсинтин та артабсинтин, сесквітерпенові лактони і моноциклічні лактони. Основними фрлавоноїдами, які містить полин гіркий, $є$ ізокверцитрин, артемізетин, артемізин, ізорамнетин, нарцисин [7]. Полин гіркий має жовчогінні, протизапальні, антисептичні, противиразкові й глистогінні властивості [8].

Трава полину звичайного (Artemisia vulgaris L.) містить ефрірну олію (0,3-0,4\%), алкалоїди, каротин, аскорбінову кислоту (в листі - до 175 мг\%), вітаміни групи В, рутин, таніни, фрлавоноїди, гіркі сесквітерпенові лактони (тауремізин та інші). До складу ефрірної олії трави входять цинеол, туйон, бронеол, камфрора [7]. Галенові 
препарати полину звичайного заспокійливо діють на нервову систему, збуджують апетит і регулюють фрункціональну діяльність травного каналу, нормалізують менструальний цикл. Відвар трави полину показаний при зниженому апетиті, млявому травленні, епілепсії, неврастенії та інших нервових захворюваннях і при нервовому безсонні [8].

Різноманітний хімічний склад рослин роду Artemisia зумовлює широкий спектр їх фрармакологічної активності, що створює передумови для дослідження протизапальної активності їх екстрактів.

Антиексудативна дія $є$ одним 3 головних критеріїв при вивченні протизапальних властивостей. Засоби, які проявляють протизапальні властивості, впливають на патофрізіологічні та біохімічні ланки запалення [9]. Запалення, яке викликали різні альтернативні чинники, відрізняється не тільки особливостями розвитку, але й фракторами, що беруть участь у його генезі. Саме тому, відповідно до Методичних рекомендацій $з$ доклінічного вивчення протизапальних засобів [9], як модельну патологію ми вибрали дві моделі запалення:

1. Дослідження протизапальної активності на моделі карагенінового набряку, що характеризує циклооксигеназний шлях запалення, за методикою Ф. П. Тринуса і співавт. У механізмі розвитку карагенінового набряку беруть участь різні медіатори запалення: в перші 30-90 хв переважно серотонін і гістамін, в інтервалі 1,52,5 год - кініни, через 2,5-5 год - простагландини $[9,10]$.

2. Дослідження протизапальної активності на моделі асептичного фрормалінового запалення - як фрлогоген використовували 2 \% розчин фрормаліну, здатність якого викликати деструкцію мембранних протеїнів було багаторазово доведено [9]. Запалення, яке спричиняє формалін, призводить як до місцевих, так і до системних змін, у результаті чого виділяються медіатори запалення, зокрема простагландини. Патогенез формалінового набряку характеризується значною деструкцією мембранних протеїнів. Пік запальної реакції припадає на 3 год після введення фрлогогену [9].

Наукові дослідження є фррагментом науково-дослідної роботи кафредри фрармації Івано-Франківського національного медичного університету “Дослідження культивованих і дикорослих лікарських рослин Західного регіону України та розробка технологій їх застосування з лікувальною метою" (номер державної реєстрації 0118U003809).

Мета дослідження - вивчити протизапальну активність екстрактів полину гіркого і полину звичайного на моделях карагенінового та фрормалінового набряків.

МЕТОДИ ДОСЛІДЖЕННЯ. ДЛЯ Порівняння отриманих показників у контрольній та експериментальних групах застосовували методи порівняння середніх величин у часовому HP Spectre 13-AE050A за допомогою програм Microsoft Office 2010 i Statistica 6.0 (Stat-Soft 2001). Достовірність усіх порівнюваних значень у тварин контрольної і дослідних груп визначали за (St) критерієм Стьюдента, також вираховували вірогідність відмінностей вибірок (р) та достовірний інтервал середньої за таблицями розподілу Стьюдента, рівень імовірності p<0,05 [11].

Дослідження та аналіз отриманих експериментальних даних проводили в порівнянні 3 препаратом із групи нестероїдних протизапальних засобів - натрію диклофенаком, який вводили в умовно-ефективній дозі $\mathrm{ED}_{50}(8 \mathrm{мг/кг),} \mathrm{і}$ кверцетином в умовно-ефективній дозі за протизапальною активністю - 5 мг/кг [12].

Експериментальні дослідження проводили на білих щурах-самцях масою 180-250 г, які перебували на звичайному режимі харчування, поділених на групи по 6 тварин у кожній.

У першій серії дослідів запальний набряк викликали шляхом введення ін'єкційним способом 0,1 мл 1 \% розчину карагеніну під апоневроз підошви задньої лапи щура. За 2 год до та відразу після введення фрлогогенного агента тваринам 1-ї і 2-ї груп перорально вводили, відповідно, екстракт полину гіркого (екстрагент - 70 \% етанол) та екстракт полину звичайного (екстрагент 70 \% етанол) у дозі 10 мг на 100 г маси тіла щура.

Для дослідження протизапальної активності на моделі асептичного фрормалінового запалення субплантарно під апоневроз підошви задньої лапи щура вводили 0,1 мл 2 \% водного розчину фрормаліну (друга серія дослідів). За 2 год до та відразу після введення $2 \%$ розчину формаліну тваринам 1-ї і 2-ї груп перорально вводили, відповідно, екстракт полину гіркого (екстрагент - 70 \% етанол) та екстракт полину звичайного (екстрагент - 70 \% етанол) у дозі 10 мг на 100 г маси тіла.

У кожній серії дослідів як препарат порівняння використовували нестероїдний протизапальний засіб - натрію диклофенак у дозі ЕД (0,8 мг/100 г маси тіла щура), який вважають еталонним протизапальним засобом (3-тя група тварин). Щурам 4-ї групи вводили кверцетин в умовно-ефективній дозі за протизапальною активністю - 5 мг/кг $[12,13]$. Тваринам контрольної групи вводили 0,1 мл 1 \% розчину карагеніну або 0,1 мл 2 \% водного розчину фрормаліну залежно від моделі запалення [9]. 
Об'єм лапи щура вимірювали онкометрично до початку експерименту, через 1, 3 і 5 год після введення фрлогогенного агента. Максимальний набряк відзначали протягом 3-5 год (табл. 1, 2) [14].

Вплив досліджуваних екстрактів оцінювали за їх здатністю пригнічувати розвиток карагенінового та формалінового набряків лапи щурів порівняно $з$ тваринами контрольної групи.

Пригнічення запальної реакції розраховували за фрормулою:

$$
A A=\left(\left(V_{k}-V_{B}\right) / V_{k}\right) \times 100
$$

де AA - антиексудативна активність, \%;

$\mathrm{V}_{\mathrm{k}}$ - приріст об'єму набряклої лапи в контролі, ум. од.;
$\mathrm{V}_{\mathrm{A}}$-приріст об'єму набряклої лапи в досліді, ум. од.

РЕЗУЛЬТАТИЙ ОБГОВОРЕННЯ. РеЗУЛЬТаТИ приросту об'єму лапи щурів залежно від дії екстрактів полину гіркого та полину звичайного при карагеніновому набряку наведено в таблиці 1.

Активність досліджуваних екстрактів полину звичайного і полину гіркого визначали за здатністю зменшувати розвиток набряку порівняно 3 контролем та виражали у відсотках, які вказували, наскільки екстракт пригнічував розвиток набряку щодо контролю, значення набряку брали за 100 \% (табл. 2).

Таблиця 1 - Антиексудативна активність екстрактів полину гіркого та полину звичайного на моделі карагенінового набряку

\begin{tabular}{||l|c|c|c|c||}
\hline \multirow{2}{*}{ Група тварин } & \multirow{2}{*}{ Доза, } & \multicolumn{2}{c||}{ Приріст об'єму лапи щура, ум. од., $\overline{\mathrm{x}} \pm \Delta \overline{\mathrm{x}}(\mathrm{n}=6)$} \\
\cline { 3 - 5 } & мг/кг & 1 год & 3 год & 5 год \\
\hline Контрольна & - & $118,22 \pm 1,49$ & $138,56 \pm 1,31$ & $149,12 \pm 0,80$ \\
\hline 1-ша (екстракт полину гіркого) & 100 & $103,73 \pm 0,35^{\star}$ & $99,04 \pm 0,70^{\star}$ & $101,13 \pm 0,52^{*}$ \\
\hline 2-га (екстракт полину звичайного) & 100 & $104,13 \pm 0,62^{*}$ & $104,90 \pm 0,48^{*}$ & $107,72 \pm 1,11^{*}$ \\
\hline 3-тя (натрію диклоренак) & 8 & $102,72 \pm 0,56^{*}$ & $92,70 \pm 0,85^{*}$ & $94,63 \pm 1,40^{*}$ \\
\hline 4-та (кверцетин) & 5 & $105,03 \pm 0,58^{*}$ & $103,70 \pm 1,08^{\star}$ & $104,67 \pm 0,63^{*}$ \\
\hline
\end{tabular}

Примітка. Тут і в таблиці 3: * - відхилення показника достовірне щодо даних групи контрольної патології (р<0,05).

Таблиця 2 - Показник пригнічення запалення екстрактами полину гіркого та полину звичайного на моделі карагенінового набряку

\begin{tabular}{|c|c|c|c|c|}
\hline \multirow{2}{*}{ Група тварин } & \multirow{2}{*}{ Назва препарату } & \multicolumn{3}{|c|}{ П Показник пригнічення запальної реакції, \% } \\
\hline & & 1 год & 3 год & 5 год \\
\hline 1-ша & Екстракт полину гіркого & 12,26 & 28,52 & 32,18 \\
\hline 2-га & Екстракт полину звичайного & 11,92 & 24,29 & 27,76 \\
\hline 3-тя & Натрію диклофренак & 13,11 & 33,10 & 36,54 \\
\hline 4-та & Кверцетин & 11,16 & 25,16 & 29,81 \\
\hline
\end{tabular}

Отримані результати (табл. 1, 2) вказують на те, що екстракти полину гіркого та полину звичайного проявляють антиоксигеназний механізм дії, інгібують синтез простагландинів та лейкотрієнів в осередку запалення. Набряк лапи щурів експериментальних груп зростав протягом 3 год з моменту введення фрлогогенного агента. Через 5 год відмічали максимальне пригнічення запалення. Протинабрякову дію екстрактів полину гіркого та полину звичайного спостерігали вже через 1 год після початку лікування порівняно 3 тваринами контрольної групи. Антиексудативна активність була різною залежно від виду введеного препарату. В контрольній групі тварин, які не отримували лікування, набряк збільшувався протягом 5 год.

Екстракт полину гіркого характеризувався дещо вираженішим антиексудативним ефектом упродовж 1-5 год карагенінового запалення, ніж екстракт полину звичайного. Дія екстракту полину гіркого була наближена до дії натрію дик- лофренаку. Екстракт полину гіркого на 1 год зменшував запалення на 12,26 \%, на 3 год - на 28,52 \%, на 5 год після введення фрлогогенного агента - на 32,18\%.

У групі тварин, лікованих екстрактом полину звичайного, спостерігали зменшення об'єму лапи щура відносно групи контрольної патології: на 1 год - на 11,92 \%, на 3 год -24,29\%, на 5 год після введення фрлогогенного агента - на $27,76 \%$.

За антиексудативною активністю протягом 5 год експерименту досліджувані речовини можна розташувати так: натрію диклофенак $(36,54 \%)>$ екстракт полину гіркого $(32,18 \%)>$ кверцетин $(29,81 \%)>$ екстракт полину звичайного $(27,76 \%)$.

Наступним фррагментом дослідження було вивчення протизапальної активності екстрактів полину гіркого та полину звичайного за умови формалінового набряку, патогенез якого характеризується значною деструкцією мембранних 
протеїнів. Протизапальну активність екстрактів полину гіркого та полину звичайного при фрормаліновому набряку наведено в таблиці 3.

Протизапальну активність досліджуваних екстрактів полину звичайного та полину гіркого визначали за здатністю зменшувати розвиток набряку порівняно з контролем та виражали у відсотках, які вказували, наскільки екстракт пригнічує розвиток набряку щодо контролю, значення набряку брали за 100 \% (табл. 4).

Таблиця 3 - Антиексудативна активність екстрактів полину гіркого та полину звичайного на моделі формалінового набряку

\begin{tabular}{||l|c|c|c|c||}
\hline \multirow{2}{*}{ Група тварин } & \multirow{2}{*}{ Доза, мг/кг } & \multicolumn{2}{c||}{ Приріст об'єму лапи щура, ум. од., $\overline{\mathrm{x}} \pm \Delta \overline{\mathrm{x}}(\mathrm{n}=6)$} \\
\cline { 3 - 5 } & & 1 год & 3 год & 5 год \\
\hline Контрольна & - & $128,11 \pm 0,66$ & $133,44 \pm 0,76$ & $156,32 \pm 0,79$ \\
\hline 1-ша (екстракт полину гіркого) & 100 & $109,00 \pm 0,73^{\star}$ & $86,35 \pm 0,59^{\star}$ & $96,32 \pm 0,56^{\star}$ \\
\hline 2-га (екстракт полину звичайного) & 100 & $111,83 \pm 0,59^{\star}$ & $92,43 \pm 0,54^{\star}$ & $102,01 \pm 0,92^{\star}$ \\
\hline 3-тя (натрію диклоренак) & 8 & $110,70 \pm 0,48^{\star}$ & $90,93 \pm 0,72^{\star}$ & $99,86 \pm 0,61^{*}$ \\
\hline 4-та (кверцетин) & 5 & $108,75 \pm 0,90^{\star}$ & $82,89 \pm 0,33^{\star}$ & $90,95 \pm 0,56^{\star}$ \\
\hline
\end{tabular}

Таблиця 4 - Показник пригнічення запалення екстрактами полину гіркого та полину звичайного на моделі формалінового набряку

\begin{tabular}{|c|c|c|c|c||}
\hline \multirow{2}{*}{ Група тварин } & \multirow{2}{*}{ Назва препарату } & \multicolumn{3}{|c|}{ Показник пригнічення запальної реакції, \% } \\
\cline { 3 - 5 } & & 1 год & 3 год & 5 год \\
\hline 1-ша & Екстракт полину гіркого & 14,92 & 35,29 & 38,38 \\
\hline 2-га & Екстракт полину звичайного & 12,71 & 30,73 & 34,74 \\
\hline 3-тя & Натрію диклофренак & 15,11 & 37,88 & 41,88 \\
\hline 4-та & Кверцетин & 13,59 & 31,86 & 36,12 \\
\hline
\end{tabular}

Аналіз отриманих у ході експерименту даних (табл. 3, 4) свідчить про те, що екстракти полину гіркого та полину звичайного проявляли достатньо виражену протизапальну дію при формаліновому набряку. Екстракт полину гіркого проявляв антиексудативну дію на 3 год на рівні 35,29 \%, на 5 год - на рівні 38,38 \%, його дія була наближена до дії рефреренс-препарату - натрію диклофенаку (на 3 год - на рівні 37,88 \%, на 5 год - на рівні 41,88 \%). Екстракт полину звичайного проявляв антиексудативну активність на 3 год на рівні 30,73 \%, на 5 год - на рівні $34,74 \%$, його дія прирівнювалась до дії кверцетину (на 3 год на рівні 31,86 \%, на 5 год - на рівні 36,12\%).

Отже, ми провели порівняльне вивчення протизапальної активності екстрактів полину гіркого та полину звичайного на двох моделях запалення, викликаних різними альтернативними чинниками. Встановлено, що при карагеніновому набряку, який характеризується циклооксигеназним шляхом запалення, екстракти полину гіркого та полину звичайного проявляли антиексудативну дію протягом усього експерименту. Найбільше пригнічення набряку спостерігали на 5 год з моменту введення фрлогогенного агента, що свідчило про вплив екстрактів полину гіркого та полину звичайного на медіатори запалення простагландини. При формаліновому набряку антиексудативна активність екстрактів проявлялась уже на 3 год і зростала до кінця експерименту, що вказувало на пригнічення активності медіаторів запалення.
Екстракти полину гіркого та полину звичайного проявляли виражену протизапальну дію вже через 3 год від початку експерименту, впливаючи на медіатори запалення.

Ми встановили виражену протизапальну дію екстрактів полину гіркого та полину звичайного, які впливають на медіатори запалення - простагландини і можуть бути використані як протизапальні засоби при запальних процесах підшлункової залози та жовчного міхура.

ВИСНОВКИ. 1. Досліджено протизапальну активність екстрактів полину гіркого та полину звичайного за умови патології різного генезу на експериментальних моделях карагенінового і формалінового набряків у щурів.

2. Встановлено антиексудативну активність екстрактів полину гіркого та полину звичайного на моделі карагенінового набряку. Екстракт полину гіркого характеризувався дещо вираженішим антиексудативним ефектом упродовж 1-5 год карагенінового запалення, ніж екстракт полину звичайного. Дія екстракту полину гіркого була наближена до дії натрію диклофенаку. Екстракт полину гіркого на 1 год експерименту зменшував запалення на 12,26 \%, на 3 год - на $28,52 \%$, на 5 год після введення фрлогогенного агента - на 32,18\%.

У групі тварин, лікованих екстрактом полину звичайного, спостерігали зменшення об'єму лапи щура відносно групи контрольної патології: на 1 год - на 11,92 \%, на 3 год - на 24,29 \%, на 
5 год після введення фрлогогенного агента - на $27,76 \%$.

За антиексудативною активністю протягом 5 год експерименту досліджувані речовини можна розташувати так: натрію диклофренак $(36,54 \%)>$ екстракт полину гіркого (32,18\%) > кверцетин $(29,81 \%)>$ екстракт полину звичайного $(27,76 \%)$.

3. Встановлено виражену антиексудативну активність екстрактів полину гіркого та полину звичайного на моделі фрормалінового набряку. Екстракт полину гіркого проявляв антиексудативну дію на 3 год на рівні 35,29 \%, на 5 год - на рівні 38,38 \%, його дія була наближена до дії ресреренс-препарату - натрію диклосренаку (на 3 год - на рівні 37,88 \%, на 5 год - на рівні 41,88 \%). Екстракт полину звичайного проявляв антиексудативну активність на 3 год експерименту на рівні 30,73 \%, на 5 год - на рівні 34,74 \%, його дія прирівнювалась до дії кверцетину (на 3 год - на рівні 31,86 \%, на 5 год - на рівні $36,12 \%)$

Конфрлікт інтересів. Автори підтверджують відсутність конфрлікту інтересів у цій публікації.

\section{СПИСОК ЛІТЕРАТУРИ}

1. Щокіна К. Г. Порівняння протиексудативної дії сучасних нестероїдних протизапальних засобів / К. Г. Щокіна, С. М. Дроговоз, Ю. М. Максимов // Ліки. 2004. - № 3-4. - С. 34-40.

2. Залигіна $€$. В. Дослідження гострої токсичності та протизапальної дії екстракту густого водно-спиртового з незрілих плодів горіха волоського / Є. В. Залигіна, В. Ю. Подплетня, В. Ю. Слєсарчук // Укр. біофрармац. журн. - 2017. - № 2 (49). - С. 44-48.

3. Кононенко А.В.Дослідження антиексудативної активності екстракту листя горобини звичайної на моделях зимозанового та карагенінового набряків / А. В. Кононенко, С. М. Дроговоз, К. Г. Щокіна // Укр. біофрармац. журн. - 2012. - № 3 (20). - С. 39-43.

4. Штрыголь С. Ю. Фармакологические свойства и проблемы безопасности применения НПВП - селективных и специсических ингибиторов циклооксигеназы-2 / С. Ю. Штрыголь // Провизор. -2005. - № 2. C. $37-42$.

5. Hawkey C. J. Nonsteroidal anti-inflammatory drugs: overall risk and management. Comlementary roles for COX 2 inhibitors and proton pump inhibitors / C. J. Hawkey, M. J. S. Langman // Gut. - 2003. - 52. P. 600-808.

6. Фармакологічне дослідження протинабрякової активності екстрактів листя та кореня лопуха / М. М. Асcаср, К. Г. Щокіна, С. М. Дроговоз, Л. В. Деримедвідь // Запорож. мед. журн. - 2011. - 13, № 3. С. $25-27$.

7. Фітохімічне вивчення ефрірної олії полину гіркого / О. В. Гречана, О. В. Мазулін, С. В. Сур [та ін.] // Фармац. журн. - 2006. - № 2. - С. 82-86.

\section{REFERENCES}

1. Shchokina, K.H., Drohovoz, S.M., \& Maksymov, Yu.M. (2004). Porivniannia protyeksudatyvnoi dii suchasnykh nesteroidnykh protyzapalnykh zasobiv [Comparison of anti-exudative effect of modern non-steroidal anti-inflammatory drugs]. Liky - Drugs, 3-4, 34-40 [in Ukrainian].
8. Medicinal importance of Artemisia absinthium Linn (Afsanteen) in Unani Medicine: A revew / A. Wasim, H. Azhar, A. Ansani, T. Tahera // Hippocratic Journal of Unani Medicine. - 2010. - 5, No. 4. - P. 117-125.

9. Доклінічні дослідження лікарських засобів : метод. рек. / за ред. О. В. Стефранова. - К. : Авіцена, 2001. - 528 c.

10. Тринус Ф. П. Нестероидные противовоспалительные средства / Ф. П. Тринус, Н. А. Мохорт, Б. М. Клебанов. - К. : Здоров'я, 1975. - 240 с.

11. Державна Фармакопея України : в 3 т. / Державне підприємство “Український науковий фрармакопейний центр якості лікарських засобів". - 2-ге вид. X. : Державне підприємство "Український науковий фрармакопейний центр якості лікарських засобів". 2015. - T. 1. - 1128 c.

12. Щокіна К. Г. Порівняння протиексудативної дії сучасних протизапальних засобів / К. Г. Щокіна, С. М. Дроговоз, В. В. Страшний // Провизор. - 2003. № 4. - С. 8-11.

13. Зупанець І. А. Експериментальне визначення протизапальної активності композиції глюкозаміну гідрохлориду та диклофенаку натрію на моделі карагенінового набряку / І. А. Зупанець, С. Б. Попов, І. А. Отрішко // Клініч. фрармація. - 2002. - № 2. C. $48-50$.

14. Acute oral toxicity of Polyalthia longifoliavar. Pendula leaf extract in Wistar albino rats / S. Chanda, R. Dave, M. Kaneria, V. Sukla // Pharm Biol. - 2012. 50. - P. 1408-1415.

2. Zalyhina Ye.V., Podpletnia V.Yu., \& Sliesarchuk V.Yu. (2017). Doslidzhennia hostroi toksychnosti ta protyzapalnoi dii ekstraktu hustoho vodno-spyrtovoho z nezrilykh plodiv horikha voloskoho [Research of acute toxicity and anti-inflammatory activity of thick water-alcohol extract of unripe walnut fruits]. Ukrainskyi biofar- 
matsevtychnyi zhurnal - Ukrainian Biopharmaceutical Journal, 2 (49), 44-48 [in Ukrainian].

3. Kononenko, A.V., Drohovoz, S.M., \& Shchokina, K.H. (2012). Doslidzhennia antyeksudatyvnoi aktyvnosti ekstraktu lystia horobyny zvychainoi na modeliakh zymozanovoho ta karaheninovoho nabriakiv [Study of anti-exudative activity of Sorbus aucuparia leaves extract on the carragenin and zimozan edema models]. Ukrainskyi biofarmatsevtychnyi zhurnal - Ukrainian Biopharmaceutical Journal, 3 (20), 39-43 [in Ukrainian].

4. Shtrygol, S.Yu. (2005). Farmakologicheskye svoystva i problemy bezopasnosti primeneniya NPVP _ selektyvnykh i spetsyficheskykh ingibitorov tsyklooksygenazy-2 [Pharmacological properties and problems of safety use of NSAIDs - selective and specific inhibitors of cyclooxygenase-2]. Provizor - Pharmacist, 2, 37-42 [in Russian].

5. Hawkey, C.J., \& Langman, M.J.S. (2003). Nonsteroidal anti-inflammatory drugs: overall risk and management. Complementary roles for COX 2 inhibitors and proton pump inhibitors. Gut., 52, 600-808.

6. Mohammad Mahmud Assaf, Shchokina, K.H., Drohovoz, S.M., \& Derymedvid, L.V. (2011). Farmakolohichne doslidzhennia protynabriakovoi aktyvnosti ekstraktiv lystia ta korenia lopukha [Pharmacological research of anti-exudative activity of extracts of common burdock leaves and root]. Zaporozhskiy medytsynskiy zhurnal Zaporozhye Medical Journal, 13 (3), 25- 27 [in Ukrainian].

7. Hrechana, O.V., Mazulin, O.V., \& Sur, S.V. (2006). Fitokhimichne vyvchennia efirnoi olii polynu hirkoho [Phitochemical study of Artemisia absinthium essential oil]. Farmatsevtychnyi zhurnal - Pharmaceutical Journal, 2, 82-86 [in Ukrainian].

8. Wasim, A., Azhar, H., Ansani, A., \& Tahera, T. (2010). Medicinal importance of Artemisia absinthium
Linn (Afsanteen) in Unani Medicine: A revew. Hippocratic Journal of Unani Medicine, 5 (4), 117-125.

9. Stephanov, O.V. (2001). Doklinichni doslidzhennia likarskykh zasobiv: metodychni rekomendatsii [Preclinical research of drugs: methodical recommendations]. Kyiv: Avitsena [in Ukrainian].

10. Trynus, F.P., Mokhort, N.A., \& Klebanov, B.M. (1975). Nesteroidnye protyvovospalitelnye sredstva [Nonsteroidal anti-inflammatory drugs]. Kyiv: Zdorovia [in Russian].

11. (2015). Derzhavna Farmakopeia Ukrainy: $v 3 t$. Derzhavne pidpryiemstvo "Ukrainskyi naukovyi farmakopeinyi tsentr yakosti likarskykh zasobiv" [State Pharmacopoeia of Ukraine: in 3 Volumes. State enterprise "Ukrainian scientific pharmacopoeia center of the quality of drugs" $2^{\text {nd }}$ edition]. Kharkiv: State enterprise "Ukrainian Scientific Pharmacopoeia Center of the Quality of Drugs" [in Ukrainian].

12. Shchokina, K.H., Drohovoz, S.M., \& Strashnyi, V.V. (2003). Porivniannia protyeksudatyvnoi dii suchasnykh protyzapalnykh zasobiv [Comparison of antiexudative activity of modern anti-inflammatory drugs]. Provyzor - Pharmacist, 4, 8-11 [in Ukrainian].

13. Zupanets, I.A., Popov, S.B., \& Otrishko, I.A. (2002). Eksperymentalne vyznachennia protyzapalnoi aktyvnosti kompozytsii hliukozaminu hidrokhlorydu ta dyklofenaku natriiu na modeli karaheninovoho nabriaku [Experimental determination of anti-inflammatory activity of composition of glucosamine of hydrochloride and diclofenac sodium on the model of carrageenic edema]. Klinichna farmatsiia - Clinical Pharmacy, 2, 48-50 [in Ukrainian].

14. Chanda, S., Dave, R., Kaneria, M., \& Sukla, V. (2012). Acute oral toxicity of Polyalthia longifolia var. pendula leaf extract in Wistar albino rats. Pharm. Biol., $50,1408-1415$.

\section{ИССЛЕДОВАНИЕ ПРОТИВОВОСПАЛИТЕЛЬНОЙ АКТИВНОСТИ ЭКСТРАКТОВ ПОЛЫНИ ГОРЬКОЙ И ПОЛЫНИ ОБЫКНОВЕННОЙ ПРИ ПАТОЛОГИИ РАЗЛИЧНОГО ГЕНЕЗА}

\section{Резюме}

Вступление. К растениям, которые имеют многовековой опыт использования в медицине, относят виды рода Полынь, которые применяют как аппетитные, глистогонные, бактерицидные, желчегонные и противовоспалительные средства, действие которых обусловлено наличием различных групп биологически активных соединений.

Цель исследования - изучить противовоспалительную активность экстрактов полыни горькой и полыни обыкновенной на моделях карагенинового и фрормалинового отеков.

Методы исследования. Для определения противовоспалительной активности экстрактов травь полыни горькой и полыни обыкновенной при патологии различного генеза использовали две методики на моделях асептического воспаления (карагениновый и фрормалиновый отеки), которые рекомендовал Государственный экспертный центр МОЗ Украины для доклинических исследований и определения антиэкссудативной активности. Исследование и анализ полученных экспериментальных данных проводили в сравнении с препаратом из группы нестероидных противовоспалительных средств - натрия диклооренаком и кверцетином. 
Результаты и обсуждение. Сравнительное изучение противовоспалительной активности экстрактов полыни горькой и полыни обыкновенной при карагениновом отеке, который характеризовался циклооксигеназным путем воспаления, показало, что они проявляли антиэкссудативное действие в течение всего эксперимента. Наибольшее угнетение отека наблюдали на 5 ч с момента введения фрлогогенного агента, что свидетельствовало о влиянии экстрактов полыни горькой и полыни обыкновенной на медиаторы воспаления - простагландины. При формалиновом отеке антиэкссудативная активность экстрактов проявлялась уже на 3 ч и повышалась до конца эксперимента, что указывало на угнетение активности медиаторов воспаления.

Вывод. Установлено выраженное противовоспалительное действие экстрактов полыни горькой и полыни обыкновенной, которые влияют на медиаторы воспаления-простагландины, их можна использовать как противовоспалительные средства при воспалительных процессах поджелудочной железы и желчного пузыря.

КЛЮЧЕВЫЕ СЛОВА: противовоспалительное действие; полынь горькая; полынь обыкновенная; карагениновый отек; формалиновый отек.

R. A. Hrytsyk ${ }^{1}$, I. V. Kireev¹, O. A. Struk², A. O. Klymenko² NATIONAL UNIVERSITY OF PHARMACY' ${ }^{1}$ KHARKIV IVANO-FRANKIVSK NATIONAL MEDICAL UNIVERSITY²

\section{RESEARCH OF ANTI-INFLAMMATORY ACTIVITY OF ARTEMISIA ABSINTHIUM L. AND ARTEMISIA VULGARIS L. EXTRACTS UNDER CONDITIONS OF THE PATHOLOGY OF DIFFERENT GENESIS}

\section{Summary}

Introduction. Artemisia genus species are used in medicine for centuries. They have appetizing, anthelmintic, bactericidal, choleretic and anti-inflammatory effects. Their activity is caused by different groups of biologically active compounds.

The aim of the study - to learn the anti-inflammatory effect of Artemisia absinthium L. and Artemisia vulgaris L. extracts using carrageenan and formalin models of edema.

Research Methods. To determine the anti-inflammatory effect of Artemisia absinthium L. and Artemisia vulgaris $L$. herb extracts under the pathology of different genesis, two techniques were used: models of carrageenin and formalin edema (aseptic inflammation). They are recommended by the State Expert Center of the Ministry of Health of Ukraine for preclinical studies and for research of anti-exudative activity. The study and analysis of the obtained experimental data were performed in comparison with non-steroidal anti-inflammatory drug - sodium diclofenac and with quercetin.

Results and Discussion. It was found that a comparative study of the anti-inflammatory effect of Artemisia $L$. herb extracts in conditions of carrageenan edema, which is characterized by cyclooxygenase way of inflammation, Artemisia absinthium L. and Artemisia vulgaris L. extracts showed anti-exudative effect throughout the experiment. The best suppression of edema was observed during fifth hour since the introduction of the phlogogenic agent. It reveals the effect of Artemisia absinthium $L$. and Artemisia vulgaris L. extracts on inflammatory mediators - prostaglandins. In condition of the formalin edema, membrane protein degradation develops and inflammatory mediators, in particular prostaglandins, are released.

Conclusions. We have established a pronounced anti-inflammatory effect of Artemisia absinthium L. and Artemisia vulgaris $L$. extracts, which affect the mediators of inflammation - prostaglandins, and can be used as antiinflammatory agents in conditions of the inflammatory processes of the pancreas and gall bladder.

KEY WORDS: anti-inflammatory effect; Artemisia absinthium L.; Artemisia vulgaris L.; carrageenan edema; formalin edema.

Отримано 23.03.20

Адреса для листування: О. А. Струк, Івано-Франківський національний медичний університет, вул. Галицька, 2, Івано-Франківськ, 76008, Україна, e-mail: sanichka5@gmail.com. 